\title{
Cytogenetic effects of malathion insecticide on somatic and germ cells of mice
}

\author{
D.M.F. Salvadori *, L.R. Ribeiro **, C.A.B. Pereira *** and W. Beçak * \\ * Serviço de Genética, Instituto Butantan, C.P. 65, 05504, São Paulo, SP (Brasil), \\ ** Laboratório de Toxicologia e Genética Toxicológica, Escola de Medicina Veterinária UFBA, Salvador-BA, 40000 (Brasil) \\ and *** Instituto de Matemática e Estatistica, USP, São Paulo, SP (Brasil)
}

(Received 24 October 1986)

(Revision received 13 May 1987)

(Accepted 25 June 1987)

Keywords: Malathion; Chromosome aberration; (Mouse).

\section{Summary}

Male mice dermally exposed to single or multiple treatment ( 5 days $/ 2$ weeks) showed that the ability of malathion to induce chromosome aberrations in somatic (bone marrow) and germ cells (primary spermatocytes) was related to the type of treatment and dose used.

Statistically significant increases of chromosome aberrations in bone marrow cells occurred after single treatment (500 and $2000 \mathrm{mg} / \mathrm{kg}$ body wt) when chromatid gaps were included and after multiple treatment $(250$ and $500 \mathrm{mg} / \mathrm{kg}$ ) when they were excluded. No dose-response relationships were observed for either treatment. In germ cells, malathion induced a significant increase of univalents in both types of treatment but structural chromosome aberrations were induced only by multiple treatment.

Malathion induced a significant decrease of the mitotic indices in the bone marrow.

Malathion (CAS No. 121-75-5), $S$-[1,2bis(ethoxycarbonyl)ethyl]- $O, O$-dimethyl phosphorodithioate, is one of the least toxic organophosphorus insecticides widely used in agriculture. Because of its increasing utilization, and knowing that some organophosphorus compounds exhibit alkylating properties (Wild, 1975), we investigated the clastogenic properties of malathion.

Tests carried out with cultured human and Chinese hamster cells showed an enhancement of

Correspondence: Dr. D.M.F. Salvadori, Serviço de Genética, Instituto Butantan, Av. Vital Brasil 1500, CEP 05504, São Paulo, SP (Brasil). sister-chromatid exchanges (SCE) (Nicholas et al., 1979; Chen et al., 1981, 1982; Nishio and Uyeki, 1981; Sobti et al., 1982).

No increase of chromosome aberrations in bone marrow cells, spermatogonia and primary spermatocytes of mice, after oral and i.p. exposure, was described by Degraeve et al. (1984) and Degraeve and Moutschen (1984). Jorgenson et al. (1976) also obtained negative evidence in a dominant lethal mutation assay with orally exposed mice.

Clastogenic effects of malathion were observed by Walter et al. (1980) in human lymphocytes stimulated with phytohemagglutinin, but no relation was revealed between the dose and the level of chromosome aberrations. Dulout et al. (1982) 
TABLE 1

CYTOGENETIC EFFECTS OF MALATHION IN BONE MARROW CELLS AFTER SINGLE TREATMENT

\begin{tabular}{|c|c|c|c|c|c|c|c|c|}
\hline \multirow{2}{*}{$\begin{array}{l}\text { Malathion } \\
(\mathrm{mg} / \mathrm{kg})\end{array}$} & \multicolumn{2}{|c|}{ Number of } & \multicolumn{5}{|c|}{ Aberrant metaphases (\%) } & \multirow{2}{*}{$\begin{array}{l}\text { Mitotic } \\
\text { index }\end{array}$} \\
\hline & Animals & $\begin{array}{l}\text { Metaphases } \\
\text { analyzed }\end{array}$ & $\begin{array}{l}\text { Chromatid } \\
\text { gap }\end{array}$ & $\begin{array}{l}\text { Chromatid } \\
\text { break }\end{array}$ & $\begin{array}{l}\text { Chromatid } \\
\text { fragment }\end{array}$ & $\begin{array}{l}\text { Total, } \\
\text { including } \\
\text { gaps }\end{array}$ & $\begin{array}{l}\text { Total, } \\
\text { excluding } \\
\text { gaps }\end{array}$ & \\
\hline 0 & 10 & 2000 & 0.15 & - & 0.80 & 0.95 & 0.80 & 2.44 \\
\hline 500 & 10 & 2000 & $0.60 * *$ & 0.10 & 0.90 & $1.60 * *$ & 1.00 & 2.06 \\
\hline 1000 & 10 & 2000 & 0.30 & 0.05 & 1.10 & 1.45 & 1.15 & $1.60 * *$ \\
\hline 2000 & 10 & 2000 & $0.45 *$ & 0.10 & 1.05 & $1.60 * *$ & 1.15 & $1.42 * *$ \\
\hline
\end{tabular}

* Significant at the $5 \%$ level $(P<0.05)$.

* * Significant at the $1 \%$ level $(P<0.01)$.

observed an increase of micronuclei in polychromatic erythrocytes of mice dermally treated but the frequencies of micronuclei were not correlated with the dose.

In this paper we report our data concerning cytotoxic and cytogenetic effects of dermally applied malathion on somatic and germ cells of mice. Dermal treatment was used because it is the main route of absorption in occupational poisoning by agricultural insecticides.

\section{Material and methods}

Commercial malathion (Malatol $100 \mathrm{CE}$, lot No. 4263-01; Cyanamid Quimica do Brasil Ltda.), was dissolved in corn oil to the desired concentration just before use. Mice used as controls were treated with corn oil only.

Swiss Webster male mice 3 weeks old were obtained from Instituto Butantan and kept in the laboratory until exposure (8-10 weeks old), with food and water ad libitum, at a photoperiod of $12: 12$ and a room temperature of $22-24^{\circ} \mathrm{C}$.

$48 \mathrm{~h}$ prior to treatment, $2-\mathrm{cm}^{2}$ areas of hair on the backs of the animals were shaven with electric clippers, taking care to avoid skin damage. Only animals in which the epidermic was apparently intact and healthy were used. Cutaneous treatment was done by spreading the malathion solutions, once a day, on the backs of mice previously cleaned with acetone to remove the keratin layer and dead cells. Treated mice were caged singly.

For the single treatment, groups of 10 animals were exposed to malathion 0 (vehicle control), 500,1000 and $2000 \mathrm{mg} / \mathrm{kg}$ body wt. The animals were killed $24 \mathrm{~h}$ after treatment and bone marrow metaphase cells were prepared according to the method described by Hsu and Patton (1969) and

TABLE 2

CYTOGENETIC EFFECTS OF MALATHION IN BONE MARROW CELLS AFTER MULTIPLE TREATMENTS

\begin{tabular}{|c|c|c|c|c|c|c|c|c|}
\hline \multirow{2}{*}{$\begin{array}{l}\text { Malathion } \\
(\mathrm{mg} / \mathrm{kg})\end{array}$} & \multicolumn{2}{|c|}{ Number of } & \multicolumn{5}{|c|}{ Aberrant metaphases (\%) } & \multirow{2}{*}{$\begin{array}{l}\text { Mitotic } \\
\text { index }\end{array}$} \\
\hline & Animals & $\begin{array}{l}\text { Metaphases } \\
\text { analyzed }\end{array}$ & $\begin{array}{l}\text { Chromatid } \\
\text { gap }\end{array}$ & $\begin{array}{l}\text { Chromatid } \\
\text { break }\end{array}$ & $\begin{array}{l}\text { Chromatid } \\
\text { fragment }\end{array}$ & $\begin{array}{l}\text { Total, } \\
\text { including } \\
\text { gaps }\end{array}$ & $\begin{array}{l}\text { Total, } \\
\text { excluding } \\
\text { gaps }\end{array}$ & \\
\hline 0 & 10 & 1000 & 0.80 & 0.20 & 0.20 & 1.20 & 0.40 & 2.42 \\
\hline 250 & 10 & 1000 & 0.50 & 0.10 & $1.20 * *$ & 1.80 & $1.30^{*}$ & 2.12 \\
\hline 500 & 10 & 1000 & 0.60 & 0.20 & $1.00 * *$ & 1.80 & $1.20^{*}$ & 2.10 \\
\hline 1000 & 10 & 1000 & 0.20 & 0.20 & 0.60 & 1.00 & 0.80 & $1.64 * *$ \\
\hline
\end{tabular}

* Significant at the $5 \%$ level $(P<0.05)$.

** Significant at the $1 \%$ level $(P<0.01)$. 

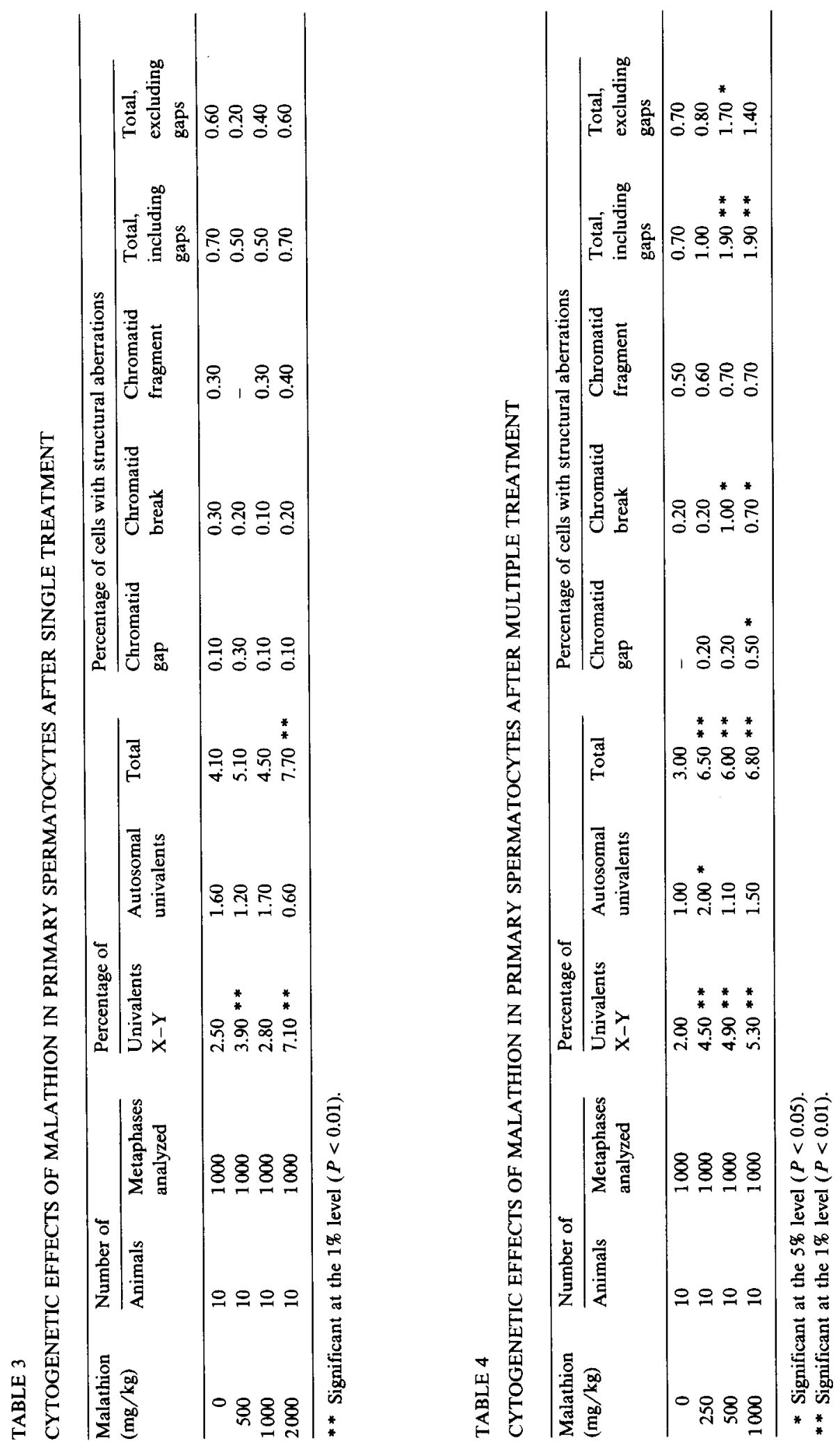
modified by Zambrano et al. (1982).

In order to obtain primary spermatocytes at the diakinesis-metaphase I stage, animals were killed 12 days after treatment which, according to Oakberg (1957), should cover the stage of DNA duplication. Air-dried chromosome preparations were made according to Evans et al. (1964).

For multiple treatment, 4 groups of 10 animals were exposed to malathion 0 (vehicle control), 250,500 and $1000 \mathrm{mg} / \mathrm{kg}$ body wt, once a day, during 5 days. After 2 days the animals were exposed again, for another period of 5 days. $24 \mathrm{~h}$ after the last exposure the animals were killed and bone marrow cells and primary spermatocytes in diakinesis-metaphase I were prepared from the same animal. The preparations were stained with aqueous Giemsa stain and coded prior to analysis.

From each animal 100 metaphases were analyzed with respect to aberrations of the chromatid and chromosome type as follows: gaps, breaks, exchanges and univalents (in germ cells). Mitotic indices were determined by analyzing 500 cells/animal.

Statistical evaluation of the data was done using a conditional test, based on an approximation to the Poisson distribution (Chakravarti et al., 1967). This test was used because the frequencies of cells with aberrations were very small in relation to the total number of cells examined.

\section{Results}

A significant increase $(P<0.01)$ of bone marrow cells with chromosome aberrations was observed after single treatment when chromatid gaps were included. It was found when animals were exposed to 500 and $2000 \mathrm{mg} / \mathrm{kg}$ body wt but not to $1000 \mathrm{mg} / \mathrm{kg}$ (Table 1 ). When chromatid gaps were excluded a significant increase $(P<0.05)$ was observed for multiple treatment with 250 and $500 \mathrm{mg} / \mathrm{kg}$ (Table 2). No correlation was found between the dose of malathion and the frequency of cells with chromosome aberrations.

A significant dose-dependent decrease $(P<$ 0.01 ) was observed for the mitotic indices with both types of treatment (Tables 1 and 2).

The frequencies of primary spermatocytes with structural chromosome aberrations were significantly increased only after multiple treatment with
500 and $1000 \mathrm{mg} / \mathrm{kg}$ when chromatid gaps were included and only with $500 \mathrm{mg} / \mathrm{kg}$ when they were excluded. Both treatments induced a significant increase of univalents mainly of $\mathrm{X}$ and $\mathrm{Y}$ (Tables 3 and 4). In both somatic and germ cells only chromatid aberrations were found.

\section{Discussion}

Malathion produces chromosome aberrations in somatic and germ cells of mice but these effects depend on the type of treatment used.

The increase of bone marrow cells with chromosome aberrations showed no dose-response relationships but a positive correlation was observed with respect to the mitotic indices. Chen et al. (1981) observed that with respect to the induction of cell cycle delay malathion is one of the most potent organophosphorus insecticides. In the cell samples analyzed after treatment with higher doses, therefore, a selection against damaged cells can be expected.

Dulout et al. (1982) using the mouse micronucleus test also found no dose-response relationships after dermal exposure to malathion. According to Ehrenberg et al. (1983) dose-response relationships are influenced by a chain of events including exposure to genotoxic agents, physicochemical processes, enzyme-catalyzed reactions and repair functions.

The absence of structural chromosome aberrations in germ cells after single treatment, as compared to multiple treatment, could be due to a fast detoxification, to protection of the testes by the blood-testes barrier, or by a lack of accumulation in the testes after single treatment.

Our results are different from those observed by Degraeve et al. (1984) and Degraeve and Moutschen (1984), who used 99\% pure malathion and other routes of exposure (oral and i.p.). It is known that commercial malathion used in agriculture contains several impurities with alkylating activities (Imamura and Talcott, 1985), which are potent inactivators of malathion carboxylesterases (Mallipudi et al., 1980) and by this potentiate its toxicity (Pellegrini and Santi, 1972; Umetsu et al., 1981).

Further studies are needed to elucidate the mechanism of the mutagenic activity of malathion. 


\section{Acknowledgments}

The authors are grateful to Ms. N. Nunes and N.S. Pereira for technical assistance.

This study was supported by grants from FAPESP, FEDIB and CNPq.

\section{References}

Chakravarti, I.M., R.G. Laha and J.R. Roy (1967) Handbook of Methods of Applied Statistics, Vol. I, Wiley, New York.

Chen, H.H., J.L. Hsueh, S.R. Sirianni and C.C. Huang (1981) Induction of sister-chromatid exchanges and cell cycle delay in cultured mammalian cells treated with eight organophosphorus pesticides, Mutation Res., 88, 307-316.

Chen, H.H., S.R. Sirianni and C.C. Huang (1982) Sister-chromatid exchanges in Chinese hamster cells treated with seventeen organophosphorus compounds in the presence of a metabolic activation system, Environ. Mutagen., 4, 621-624.

Degraeve, N., and J. Moutschen (1984) Genetic and cytogenetic effects induced in the mouse by an organophosphorus insecticide: malathion, Environ. Res., 34, 170-174.

Degraeve, N., M.-C. Chollet and J. Moutschen (1984) Cytogenetic and genetic effects of subchronic treatments with organophosphorus insecticides, Arch. Toxicol., 56, 66-67.

Dulout, F.N., O.A. Olivero, H. von Guradze and M.C. Pastori (1982) Cytogenetic effects of malathion assessed by micronucleus test, Mutation Res., 105, 413-416.

Ehrenberg, L., E. Moustacchi and S. Osterman-Golkar (1983) Dosimetry of genotoxic agents and dose-response relationships of their effects, Mutation Res., 123, 121-182.

Evans, E.F., G. Breckon and C.E. Ford (1964) An air-drying method for meiotic preparations from mammalian testes, Cytogenetics, 3, 289-294.

Hsu, T.C., and J.L. Patton (1969) Bone-marrow preparations for chromosome studies, in: K. Benirschke (Ed.), Comparative Mammalian Cytogenetics, Springer, Berlin, pp. $454-460$.

Imamura, T., and R.E. Talcott (1985) Mutagenic and alkylat- ing activities of organophosphate impurities of commercial malathion, Mutation Res., 155, 1-6.

Jorgenson, T.A., C.J. Rushbrook and G.W. Newell (1976) 'In vivo' mutagenesis investigations of ten commercial pesticides, Toxicol. Appl. Pharmacol., 37, 109.

Mallipudi, N.M., R.E. Talcott, A. Ketterman and T.R. Fukuto (1980) Properties and inhibition of rat malathion carboxylesterases, J. Toxicol. Environ. Health, 6, 585-596.

Nicholas, A.H., M. Vienne and H.V.D. Berghe (1979) Induction of sister-chromatid exchanges in cultured human cells by an organophosphorus insecticide: malathion, Mutation Res., 67, 167-172.

Nishio, A., and E.M. Uyeki (1981) Induction of sister-chromatid exchanges in Chinese hamster ovary cells by organophosphate insecticides and their oxygen analogs, $\mathbf{J}$. Toxicol. Environ. Health, 8, 939-946.

Oakberg, E.F. (1957) Duration of spermatogeneses in the mouse, Nature (London), 180, 1137-1138.

Pellegrini, G., and R. Santi (1972) Potentiation of toxicity of organophosphorus compound containing carboxylic ester functions toward warm-blooded animals by some organophosphorus impurities, J. Agric. Food Chem., 20, 944-950.

Sobti, R.C., A. Krishan and C.D. Pfaffenberger (1982) Cytokinetic and cytogenetic effects of some agricultural chemicals on human lymphoid cells in vitro: organophosphate, Mutation Res., 102, 89-102.

Umetsu, N., N.M. Mallipudi, R.F. Toia, R.B. March and T.R. Fukuto (1981) Toxicological properties of phosphorothioate and related esters present as impurities in technical organophosphorus insecticides, J. Toxicol. Environ. Health, 7, 481-497.

Walter, Z., A. Czajkowska and K. Lipecka (1980) Effect of malathion on the genetic material of human lymphocytes stimulated by phytohemagglutinin (PHA), Hum. Genet., $53,375-381$.

Wild, D. (1975) Mutagenicity studies on organophosphorus insecticides, Mutation Res., 32, 133-150.

Zambrano, M.A., H.J. Targa and M.N. Rabello-Gay (1982) Physiological saline solutions as a useful tool in micronucleus and metaphase slide preparations, Stain Technol., $57,48-49$. 